\title{
UPACARA ADAT BERSIH DESA DELUNGAN,DUSUN MACANAN
}

\author{
Jauhar Azhar \\ Pendidikan IPS FKIP ULM \\ Emaill: jauharazhar00@gmail.com
}

\begin{abstract}
ABSTRAK
kearifan lokal merupakan suatu pandangan dan pengetahuan tradisional yang menjadi acuan dalam berperilaku dan telah dipraktikkan secara turun-temurun untuk memenuhi kebutuhan dan tantangan dalam kehidupan suatu masyarakat.. Artikel ini disusun untuk memperdalam kajian mengenai situs batu di Dusun Dalungan dengan tradisi upacara adat bersih desa yang selalu diadakan setiap 1 tahun sekali. Dusun Dalungan sendiri merupakan nama sebuah Dusun di Desa Macanan, Kecamatan Kebakkramat, Kabupaten Karanganyar.Teknik pengumpulan data menggunakan wawancara dan observasi. Hasil penelitian mendeskripsikan bahwa dari tradisi itulah dapat kita ketahui bahwa masyarakat Dusun Dalungan sebagian besar masih percaya akan kekuatan dhayang ( penunggu ) punden batu kenthéng tersebut, serta dapat kita ketahui bahwa masyarakat sangat menjaga tradisi dari para leluhur.
\end{abstract}

\section{Pendahuluan}

Ekstitensi sebuah bangsa terwujud melalui penggalian kearifan lokal pada setiap wilayah di negeri ini Kearifan lokal merupakan gagasan-gagasan setempat (lokal) yang bersifat bijaksana, penuh kearifan, bernilai baik yang tertanam dan diikuti oleh anggota masyarakatnya (Sartini, 2004: 111). Pengertian lain namun senada tentang kearifan lokal juga diungkapkan oleh Zulkarnain dan Febriamansyah (2008: 72) berupa prinsipprinsip dan cara-cara tertentu yang dianut, dipahami, dan diaplikasikan oleh masyarakat lokal dalam berinteraksi dan berinterelasi dengan lingkungannya dan ditransformasikan dalam bentuk sistem nilai dan norma adat.

Dengan demikian kearifan lokal merupakan suatu pandangan dan pengetahuan tradisional yang menjadi acuan dalam berperilaku dan telah dipraktikkan secara turuntemurun untuk memenuhi kebutuhan dan tantangan dalam kehidupan suatu masyarakat. Kearifan lokal berfungsi dan bermakna dalam masyarakat baik dalam pelestarian sumber daya alam dan manusia, pemertahanan adat dan budaya, serta bermanfaat untuk kehidupan. Hal ini juga membuktikan bahwa kearifan lokal juga berpengaruh dengan 
bentuk geografis yang ada yang sepertihalnya daya dukung alam (geografi) etnis Banjar didominasi oleh keberadaan perairan sungai yang menjanjikan terselenggaranya aktivitas pelayaran serta Seperti halnya kain sasaringan khas Kalimantan Selatan yang diwariskan secara turun-temurun. Selain geografis faktor lainya adalah sosial yaitu sperti halnya masyarakat yang bermukim bantaran sungai Kelurahan Sungai Jingah Kota Banjarmasin.

Upacara adat bersih desa merupakan slametan atau upacara adat jawa untuk memberikan sesaji kepada danyang desa. Bersih desa dilakukan masyarakat dusun untuk membersihkan desa dari roh-roh jahat yang mengganggu. Maka sesaji diberikan kepada danyang, karena danyang dipercaya sebagai penjaga sebuah desa.

Artikel ini disusun untuk memperdalam kajian mengenai situs batu di Dusun Dalungan dengan tradisi upacara adat bersih desa yang selalu diadakan setiap 1 tahun sekali. Dusun Dalungan sendiri merupakan nama sebuah Dusun di Desa Macanan, Kecamatan Kebakkramat, Kabupaten Karanganyar.Selain itu saya juga ingin mengetahui keistimewaan-keistimewaan apa saja yang ada dalam situs batu kentheng di Dusun Dalungan tersebut, serta mengetahui keunikan-keunikan tradisi upacara adat bersih desa yang rutin di gelar setiap 1 tahun sekali tepatnya pada hari jum'at legi di bulan ruwah. Serta melihat sifat gotong royong masyarakat desa delungan dalam menjalankan dan melestarikan kearifan ini. Seperti halnya Masyarakat Banjar desa Andhika yang menjalankan tradisi bahaul yang identik dengan budaya gotong royong adalah masyarakat yang hidup bersama menghasilkan kebudayaan, kebiasaan, nilai dan tradisi. Seperti halnya interaksi sosial yaitu merupakan hubungan timbal-balik yang terjalin saat kontak sosial berlangsung. Interaksi sosial dibedakan menjadi dua yakni asosiatif dan disosiatif.Adapun bentuk interaksi sosial asosiatif hanya pada aspek kerjasama. Kerjasama dilakukan saat pembuatan hingga saling membantu untuk menurunkan jukung ke sungai. Bentuk interaksi sosial yang demikian, patut dimaknai sehingga merekatkan hubungan sosial masyarakat.Bintarto (Fasya, 1987: 2) menegaskan bahwa kesadaran warga desa untuk terlibat aktif karena mereka menyadari tidak bisa hidup sendiri tanpa perlindungan masyarakatnya dan lingkungan alam sekitarnya.

\section{Pembahasan}

\section{A. Sejarah Batu Kentheng Dusun Dalungan, Macanan dan Tradisi Upacara Adatnya.}

Di Dusun Dalungan terdapat sebuah keunikan, baik dari segi budaya maupun cagar budayanya. Didusun Dalungan ini terdapat sebuah situs batu kuno yang memiliki nilai sejarah dan nilai kesakralan yang tinggi. Oleh masyarakat sekitarsitus batu ini disebut dengan nama "batu kenthéng". Namun tidak hanya itu saja, situs batu ini juga disebut punden oleh masyarakat sekitar. Situs batu ini terletak di tengah Dusun 
Dalungan, Desa Macanan. Tempat situs batu kenthéng ini berada di dalam sebuah punden yang dibagian sampingnya dipagari oleh tembok dari batu-bata yang didalamnya juga terdapat sebuah pohon sawo yang berukuran besar yang tumbuh subur di dekat situs batu ini sebagai pelindung batu dari terik matahari.

Situs batu di Dusun Dalungan ini merupakan sebuah situs batu berbentuk batu yoni atau lebih dikenal dengan batu lumpang. Disebut batu lumpang dikarenakan di bagian atas batu tersebut ada sebuah cekungan berbentuk seperti lumpang. Selain itu dibagian depan batu tersebut terdapat sebuah arca kecil. Situs batu ini telah ada sebelum zaman penjajahan Belanda di mulai. Namun, belum dapat diketahui secara pasti berapa usia situs batu ini, dikarenakan tidak ada bukti yang kuat mengenai usia situs batu tersebut. Namun, jika di tinjau dari penjelasan Bapak Merto Samiyun sebagai juru kunci situs batu kenthéng yang ke-4 mengatakan bahwa situs batu ini telah ada sebelum zaman penjajahan tejadi, jadi dapat diperkirakan usia batu kenthéng tersebut \pm 300 tahunan. Disitus batu ini diyakini oleh masyarakat sekitar di jaga oleh 3 penunggu, yaitu Kyai Panjipuro dan Nyai Panjipuro serta Kyai Gendongali hal ini yang menjadikan batu tersebut sangat disakralkan oleh masyarakat sekitar. Punden tempat situs batu kenthéng ini juga sempat mengalami perbaikan dan pemugaran pada tanggal 29 Juli 1983. Bagian yang diperbaiki dari punden tempat situs batu itu adalah bagian lantai punden serta bagian tembok pagar punden. Tidak hanya itu saja, bagian tembok punden juga dicat kembali agar terlihat lebih bagus lagi.

Selain itu batu kenthéng ini juga memiliki keistimewaan-keistimewaan yang tidak dimiliki oleh situs batu yang lain. Hal inilah yang menjadikan situs batu kenthéng ini sangat disakralkan dan dijaga dengan baik oleh masyarakat sekitar. Salah satu keunikan dari batu ini yaitu dibagian atas situs batu kenthéng tersebut terdapat sebuah cekungan yang didalamnya terdapat sebuah mata air yang tidak akan pernah kering walau di musim kemarau sekalipun.Menurut Bapak Merto Samiyun air dari dalam situs batu ini juga dapat menyembuhkan berbagai macam penyakit. Menurut penjelasan Bapak Merto Samiyun pada zaman penjajahan Belanda dulu, sempat ada pemindahan tempat situs batu kenthéng tersebut.Situs batu ini dulunya akan dipindahkan kedaerah Dusun Nayan, Nangsri,Kebakkramat.Namun pada saat proses pemindahan banyak sekali halangan yang dihadapi, cara yang dilakukan oleh masyarakat sekitar untuk memindahkan batu tersebut dengan menggunakan kendaraan ternyata mengalami kegagalan.Karena cara yang dilakukan hasilnya nihil akhirnya masyarakat memutuskan untuk memindahkan batu tersebut dengan cara dipanggul bersama-sama.Barulah dengan cara ini batu tersebut dapat dipindahkan dengan mudah, padahal berat batu tersebut \pm 1 ton. Namun keesokan harinya batu kenthéng tersebut kembali lagi ketempat semula.

Tidak hanya itu saja,pada saat perbaikan lokasi batu tersebut masyarakat sekitar memutuskan untuk mengecat batu itu sekalian, namun ternyata batu tersebut 
tidak bisa diwarnai atau di cat dari situlah masyarakat daerah setempat mempercayai bahwa situs batu kentheng tersebut memiliki kekuatan magis yang sangat tinggi dan dari situlah masyarakat daerah setempat senantiasa menjaga kesakralan situs batu tersebut.Oleh masyarakat sekitar situs batu kenthéng ini juga digunakan untuk sarana berdoa, banyak yang mempercayai jika batu tersebut dapat menjadi perantara kepada sang pencipta.Jika orang yang berdoa di sana dan memiliki niat yang tulus dan hati yang bersih maka apa yang menjadi keinginannya akan terpenuhi.Menurut Bapak Merto Samiyun jika kita ingin berkunjung kepunden batu tersebut harus membawa sebuah dupa atau yang lebih dikenal dengan nama ketike. Ketike adalah sebuah benda berwarna hitam yang berbentuk cair dan padat. Benda ini merupakan sebuah syarat saat hendak masuk kedalam punden. Dupa atau ketike tadi dibakar didalam punden sebagai syarat untuk masuk kedalam punden batu tersebut, setelah ketike tadi dibakar, juru kunci batu tersebut akan membacakan sebuah doa dan meminta ijin kepada penunggu batu tersebut.Selain syarat tadi ada syarat yang lebih penting ketika hendak berkunjung ke punden batu ini yaitu hanya boleh dihari jum'at legi dikarenakan masyarakat sekitar percaya bahwa pada hari ini merupakan hari yang baik dan tepat pada pukul 24:00 WIB.Alasan dipilihnya waktu ini adalah dikarenakan pada waktu ini keadaan sekitar punden lebih tenang dan hening maka seseorang yang akan berdoa akan menjadi khusyuk. Selain itu dari hasil pengamatan kami terhadap situs batu tersebut,dapat kami ketahui bahwa situs batu kenthéng tersebut masih dijaga keberadaannya, terbukti dengan adanya kesadaran masyarakat dalam menjaga kebersihan dan menjaga punden batu tersebut. Bapak Merto Samiyun mengatakan bahwa punden batu tersebut rutin dibersihkan dengan cara menyapu halaman sekitar punden. Tidak hanya itu, punden batu ini juga wajib dibersihkan pada hari jum'at legi. Di hari jum'at legi tidak hanya bagian punden saja yang dibersihkan melainkan batu kenthéng itu sendiri juga ikut dibersihkan di gosok perlahan menggunakan kain bersih/kain yang halus dengan tujuan agar kondisi batu tetap bersih dan supaya tidak merusak bentuk situs batu tersebut. Jadi dapat kami lihat bagaimana masyarakat sangat menjaga keberadaan situs batu tersebut. Dan dapat kami ketahui bahwa bentuk batu dan warna batu kenthéng dari zaman dahulu sampai sekarang masih sama atau masih dalam bentuk yang asli walaupun dulu pernah ada rencana untuk memberi warna pada batu tersebut namun ternyata situs batu tersebut tidak dapat diberi warna jadi bentuk dan warna batu kentheng itu masih asli tidak berubah dari dulu sampai sekarang. Kearifan lokal seperti ini harusnya dapat dijadikan bahan ajar pembelajaran IPS di sekolah-sekolah didaerah tersebu walaupun memiliki peran yang strategis dalam perkembangan kurikulum pendidikan IPS di sekolah tapi sampai saat ini belum perkembangan yang optimal (Hutama, 2016) menjelaskan bahwa kondisi pembelajaran saat ini IPS menunjukkan pengabaian terhadap budaya lokal sebenarnya dapat berfungsi untuk membangun karakter siswa. 


\section{B. Tradisi Upacara Adat Bersih Desa}

Punden batu ini juga berkaitan erat dengan tradisi upacara adat bersih desa yang rutin dilakukan setiap 1 tahun sekali tepatnya di hari jum'at legi di bulan ruwah.Upacara adat ini termasuk upacara religi, yang diselenggarakan dengan maksud agar masyarakat sekitar khususnya Dusun Dalungan mendapatkan rahmat dan berkah dari Allah Swt. dan terhindar dari segala hal yang bersifat tidak baik.Tujuan lain dari upacara bersih desa ini adalah agar Dusun Dalungan selalu aman, tentram dan makmur. Hal ini juga sama dilakukan di daerah banjarmasin yang bernama tradisi batahlil,yaitu berdoa di langgar dengan tujuan meningkatkan nilai religius dan peduli kepada sosial. Upacara adat bersih desa ini telah dilaksanakan sejak dahulu kala hingga sekarang secara turun -temurun, dikarenakan tradisi ini adalah warisan budaya dari leluhur yang sangat dihormati oleh masyarakat sekitar. Adanya Upacara bersih desa ini sangat berkaitan erat denganpunden batu kenthéng di dusun Dalungan. Upacara bersih desa ini juga dimaksudkan untuk memberi penghormatan pada leluhur penunggu punden batu tersebut yang dipercayai oleh masyarakat sekitar bahwa batu Kethéng tersebut dijaga oleh tiga penunggu. Dalam pelaksanaan upacara bersih desa ini banyak sekali persiapan yang harus dilakukan sebelum dimulainnya acara ini salah satu syarat yang harus ada dalam pelaksanaan upacara ritual bersih Desa Dalungan ini adalah pertunjukan seni tayub.

Seni tayub sendiri merupakan salah satu bagian terpenting dalam acara tersebut, karena merupakan syarat yang mutlak dalam kegiatan upacara adat bersih desa ini. Adanya pertunjukan seni tayub ini dimaksudkan untuk memberi sesaji kepada penunggu batu kenthéng tersebut. Pertunjukan tayub sendiri merupakan sebuah sarana ritual untuk berhubungan langsung dengan leluhur. Selain itu, digunakannya seni tayub dalam upacara bersih desa dikarenakan menurut masyarakat sekitar. Seni Tayub memiliki arti yang sama dengan punden batu kentheng tersebut, yakni sebagai simbol kesuburan. Hal inilah yang menjadikan seni tari tayub sebagai syarat mutlak yang wajib dipenuhi dalam pelaksanaan upacara adat tersebut.

Proses upacara bersih desa dimulai pada sore hari sekitar pukul 15.00-17.30 WIB. Acara ini dimulai dengan kegiatan kenduri atau yang lebih dikenal dengan nama bancaan. Pada acara kenduri biasannya masyarakat menyediakan berbagai makanan yang menjadi syarat dalam sebuah kenduri, seperti contohnya nasi liwet,gudangan,ayam,pisang dan masih banyak lagi. Setelah acara kenduri selesai barulah dilanjutkan dengan acara selanjutnya yakni seni tayub dengan diawali ledhek ( penari ) tayub didepanbatu kenthéng tersebut atau dibagian teras tempat batu tersebut berada dengan tujuan untuk menghibur para leluhur atau penunggu punden batu tersebut. Biasanya ledhek ( penari ) tayub akan menampilkan 3-5 lagu serta menari selama \pm 30 menit. Tarian dan lagu yang dibawakan dalam acara inia adalah tarian dan lagu yang 
pokok. Acara ini merupakan acara pokok dalam kegiatan upacara bersih desa tersebut. Setelah acara pokok ini selesai,kemudian dilanjutkan dengan pertunjukan seni tayub, namun tempatnya tak lagi di depan punden atau diteras punden melainkan dipindahkan ke tengah desa atau diperempatan Dusun Dalungan. Acara ini merupakan acara terakhir, Demikian susunan acara dalam kegiatan upacara bersih desa tersebut. Upacara bersih desa ini menghabiskan dana sekitar Rp 9.000.000,00 - Rp 10.000.000,00.

Tradisi upacara adat ini adalah agenda yang paling penting bagi masyarakat sekitar Dusun Dalungan, karena sudah menjadi adat istiadat di dusun tersebut.

Dan dalam waktu pelaksanaannya tidak boleh di tunda-tunda, harus tepat waktu yaitu pada hari jum 'at legi di bulan ruwah. Masyarakat meyakini jika pelaksanaannya ditunda maka akan terjadi sesuatu yang tidak diinginkan oleh masyarakat sekitar. Dari tradisi itulah dapat kita ketahui bahwa masyarakat Dusun Dalungan sebagian besar masih percaya akan kekuatan dhayang ( penunggu ) punden batu kenthéng tersebut, serta dapat kita ketahui bahwa masyarakat sangat menjaga tradisi dari para leluhur.

\section{Kesimpulan}

Dari Artikel diatas dapat disimpulkam bahwa di Dusun Dalungan terdapat sebuah keunikan, baik dari segi budaya maupun cagar budayanya. Didusun Dalungan ini terdapat sebuah situs batu kuno yang memiliki nilai sejarah dan nilai kesakralan yang tinggi. Oleh masyarakat sekitarsitus batu ini disebut dengan nama "batu kenthéng". Namun tidak hanya itu saja, situs batu ini juga disebut punden oleh masyarakat sekitar. Situs batu di Dusun Dalungan ini merupakan sebuah situs batu berbentuk batu yoni atau lebih dikenal dengan batu lumpang. Disebut batu lumpang dikarenakan di bagian atas batu tersebut ada sebuah cekungan berbentuk seperti lumpang. Selain itu dibagian depan batu tersebut terdapat sebuah arca kecil. Situs batu ini telah ada sebelum zaman penjajahan Belanda di mulai.

Punden batu ini juga berkaitan erat dengan tradisi upacara adat bersih desa yang rutin dilakukan setiap 1 tahun sekali tepatnya di hari jum'at legi di bulan ruwah.Upacara adat ini termasuk upacara religi, yang diselenggarakan dengan maksud agar masyarakat sekitar khususnya Dusun Dalungan mendapatkan rahmat dan berkah dari Allah Swt. dan terhindar dari segala hal yang bersifat tidak baik. Tujuan lain dari upacara bersih desa ini adalah agar Dusun Dalungan selalu aman, tentram dan makmur.Upacara adat bersih desa ini telah dilaksanakan sejak dahulu kala hingga sekarang secara turun temurun, dikarenakan tradisi ini adalah warisan budaya dari leluhur yang sangat dihormati oleh masyarakat sekitar.

Upacara bersih desa ini juga dimaksudkan untuk memberi penghormatan pada leluhur penunggu punden batu tersebut yang dipercayai oleh masyarakat sekitar 
bahwa batu Kethéng tersebut dijaga oleh tiga penunggu. Dalam pelaksanaan upacara bersih desa ini banyak sekali persiapan yang harus dilakukan sebelum dimulainnya acara ini salah satu syarat yang harus ada dalam pelaksanaan upacara ritual bersih Desa Dalungan ini adalah pertunjukan seni tayub. Proses upacara bersih desa dimulai pada sore hari sekitar pukul 15.00-17.30 WIB. Acara ini dimulai dengan kegiatan kenduri atau yang lebih dikenal dengan nama bancaan. Setelah acara kenduri selesai barulah dilanjutkan dengan acara selanjutnya yakni seni tayub dengan diawali ledhek ( penari ) tayub didepanbatu kenthéng tersebut atau dibagian teras tempat batu tersebut berada dengan tujuan untuk menghibur para leluhur atau penunggu punden batu tersebut. Tradisi upacara adat ini adalah agenda yang paling penting bagi masyarakat sekitar Dusun Dalungan, karena sudah menjadi adat istiadat di dusun tersebut.

Dan dalam waktu pelaksanaannya tidak boleh di tunda-tunda, harus tepat waktu yaitu pada hari jum 'at legi di bulan ruwah. Masyarakat meyakini jika pelaksanaannya ditunda maka akan terjadi sesuatu yang tidak diinginkan oleh masyarakat sekitar. Selain itu saat upacara ada berlangsung juga dapat mengangkat ekonomi masyarakat sekitar khususnya warga desa delugan dengan berjualan kuliner saat acara berlangsung.

Upaya pemahaman konsep esensial hubungan antara manusia dan lingkungan sebagai kajian geografi dapat diintegrasikan dalam muatan mata pelajaran IPS melalui pengetahuan konsep dan pengaplikasiannya dalam kehidupan sehari-hari. Peranan penting manusia agar memiliki sensitivitas terhadap lingkungan berkaitan dengan pesebaran penduduk juga melalui nilai-nilai keunggulan potensi local untuk memecahkan masalah yang ada di sekitar peserta didik, serta cinta tanah air dalam memperkuat bangsa dan negara.

\section{Daftar Pustaka}

Subiyakto, Bambang. Mutiani. (2019). Internalisasi Nilai Pendidikan Melalui Aktivitas Masyarakat Sebagai Sumber Belajar Ilmu Pengetahuan Sosial. Jurnal Studi Islam dan Humaniora. Universitas Lambung Mangkurat. Vol. 17. No 1. 137-166

Subiyakto,bambang. (2020). Sungai Dan Kehidupan Masyarakat Banjar: Penguatan Lokalitas Dalam Wacana Pendidikan Ips Yang Responsif. Banjarmasin: Program Studi Pendidikan IPS FKIP ULM Banjarmasin

Subiyakto, Bambang.,dkk. (2016). Nilai-Nilai Gotong Royong Pada Tradisi Bahaul Dalam Masyarakat Banjar Di Desa Andhika Sebagai Sumber Pembelajaran Ips. Jurnal Vidya Karya | Volume 31, Nomor 2.

Jumriani.(2018).Kegiatan Produksi Dan Distribusi Dikampung Sasirangan Sebagai Sumber Belajar Ips. Jurnal Pendidikan dan Pembelajaran Ilmu Pengetahuan Sosial. Vol 7. No 1.Hal 105-118. 
Jumriani.,dkk. (2019). Social Interaction Sasirangan Traders Village In The City Of Banjarmasin As A Learning Resources On Social Studies. The Innovation of Social Studies Journal. FKIP Lambung Mangkurat University. Vol. 1. No 1.

Sartini. (2004). Menggali Kearifan Lokal Nusantara: Sebuah Kajian Filsafat. Jurnal Filsafat, 37, 111-120.

Zulkarnain, A.Ag., \& Febriamansyah, R. (2008). Kearifan Lokal dan Pemanfaatan dan Pelestarian Sumberdaya Pesisir. Jurnal Agribisnis Kerakyatan,1, 69-85.

Permana, Raden Cecep Eka., dkk. (2011). Kearifan Lokal Tentang Mitigasi Bencana Pada Masyarakat Baduy. Makara, Sosial Humaniora. Universitas Indonesia. Vol 15. No 1. Hal 67-76.

Fasya, G.K. Gotong Royong Dalam Kehidupan Masyarakat. Prisma, 3.

Handy,Muhammad Rezky Noor.,dkk.(2020). The Religious Values in Tradition of Batahlil in Banjar Pahuluan Community. Universitas Lambung Mangkurat.Vol 2,No 1.

Putro, Herry Porda Nugroho.,dkk. (2020). Social Life of the Community: Perspective of Riverbanks Community in Sungai Jingah, Banjarmasin.The Kalimantan Social Studies Journal. Vol 1. No 2.

Subiyakto,Bambang.,dkk. (2020). Social Interaction of Jukung Craftsmen in Pulau Sewangi, Alalak, Barito Kuala.The Innovation Of Social Studies Journal.Vol. 1, No. 2.

Abbas, Ersis Warmansyah.,Jumriani.(2020).Culinary Identification in the Banua Anyar Culinary Tourism Area; aContribution for Tourism in Banjarmasin City. The Innovationof Social Studies Journal.Vol.2, No. 1.

Rahmatina., dkk. (2021). Contribution of Geography Concepts in the Content of Junior High School Social Studies Subjects. The Kalimantan Social Studies Journal. Vol 2. No 2.

\section{LAMPIRAN}




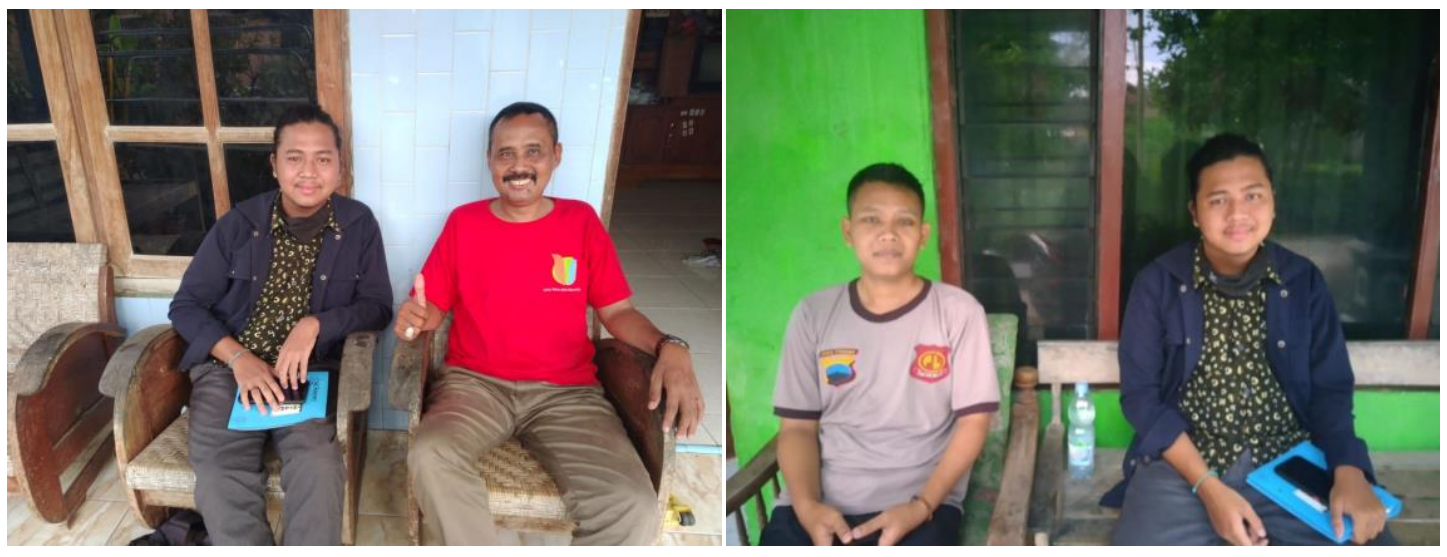

\section{Bukti Upload OSF}

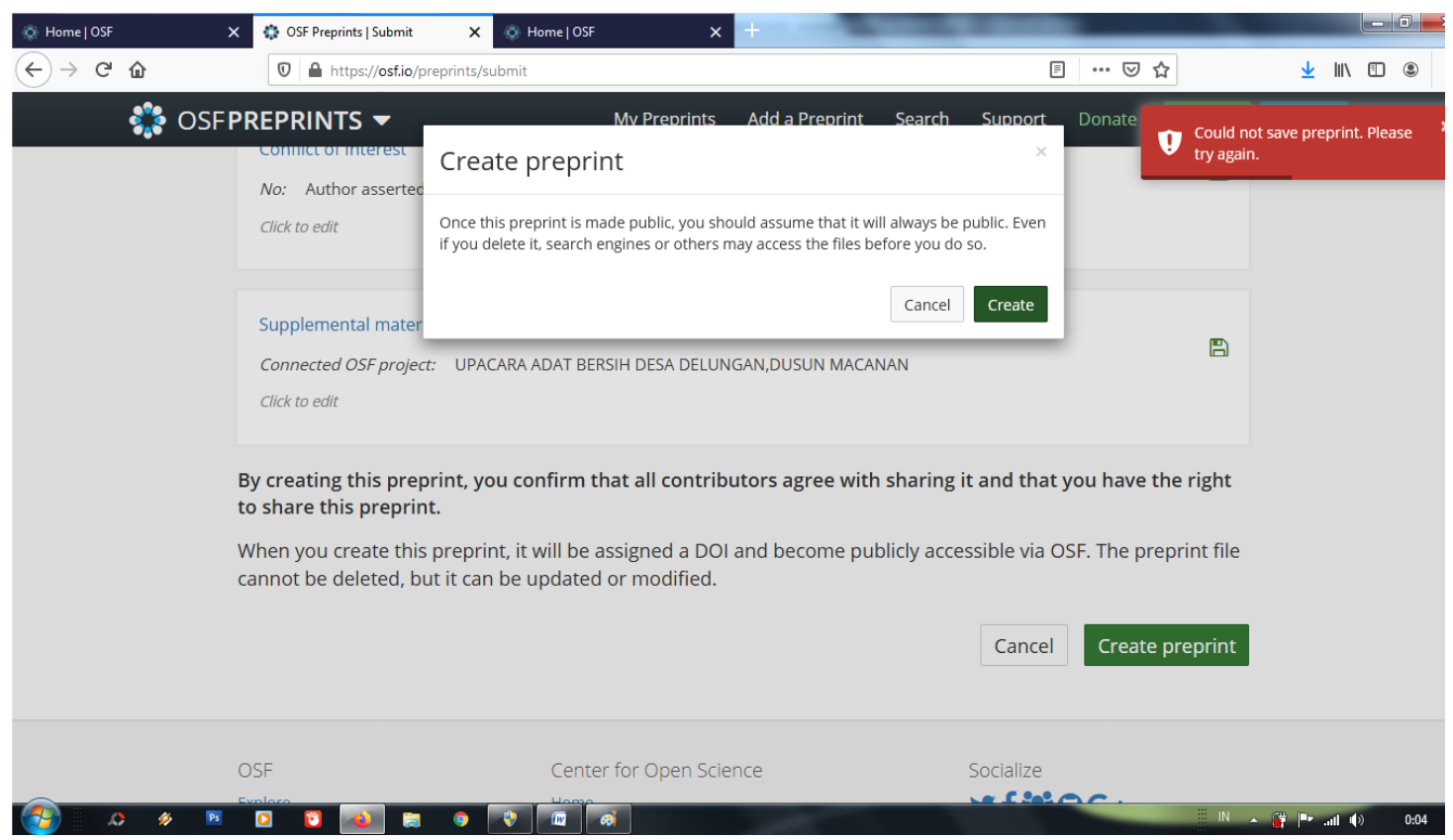

